\title{
WOKÓŁ JĘZYKA PISM WIZYJNYCH ŚW. HILDEGARDY Z BINGEN
}

\section{WSTEP}

Św. Hildegarda z Bingen, jedna z najciekawszych postaci XII-wiecznej myśli chrześcijańskiej nie uważała się za teologa, ani w ogóle za osobę uczoną - dodatkowo jej pozycję jako myślicielki utrudniał fakt, iż była kobietą - to pozostawiła po sobie wielkie dzieło, będące kompendium XII-wiecznej tradycji chrześcijańskiej, którą twórczo interpretowała.

Ksieni z Bingen porusza się po torach wyznaczonych przez nauczanie Kościoła, Pismo Święte i tradycję, ale otwarta jest też na nowe idee. W zastane formy tradycji chrześcijańskiej wlewa nowe treści, co pozwala odkryć na nowo wiele dobrze znanych koncepcji teologicznych czy filozoficznych. Fundamentalny dla myśli chrześcijańskiej fakt stworzenia przez Boga wszystkiego z nicości jest dla niej punktem wyjścia, z którego rozwija swą niezwykle oryginalną i porywającą wizję świata jako dynamicznego dzieła Bożego. Świat jest dla niej wspaniałym dziełem Bożym, tak zaplanowanym i ukształtowanym, aby wszystkie jego elementy przez wzajemne współdziałanie osiągnęły właściwą sobie doskonałość.

Przedmiotem wizji Hildegardy zawsze jest kosmos jako całość, a każde z jej pism wizyjnych kończy się spojrzeniem z końca świata i pojawieniem się kosmicznego Chrystusa. Kosmiczna rozciągłość jej perspektywy prezentuje się, szczególnie mocno, w wywołujących 
wielkie wrażenie obrazach, które Hildegarda opisuje w swoich pismach. Z kosmicznej symboliki pochodzą też porównania duszy z elementami natury (wiatrem, słońcem), przedstawiające obrazowo siły, przez które dusza odnosi się do własnego ciała, a przez nie do całego kosmosu. Takie porównania wyrażone przez Hildegardę w prostym języku i z bezpośrednią żywiołowością, sygnalizują coś więcej niż tylko literackie zainteresowanie dla kosmicznych wizji.

W swoich wizjach opisuje Hildegarda głównie człowieka jako najwspanialsze dzieło Boże oraz poszczególne elementy stworzonego świata. We wszystkich odnajduje ukryte powiązanie z człowiekiem oraz ze Stwórcą. Można powiedzieć, iż cały jej wysiłek polega na odnajdywaniu śladów Boga w człowieku i stworzeniu oraz przekazywaniu tej wiedzy innym ludziom, aby wszyscy jak najszybciej i jak najpełniej mogli poznać swoje miejsce w hierarchii stworzeń i włączyć się w dynamiczną drogę powrotu do Stwórcy. Hildegarda pragnie więc osiągnąć mądrość, która pozwoli jej ujrzeć świat we właściwym świetle, tak jak był zaplanowany i stworzony przez Boga.

Osiągnięcie takiej mądrości jest dla człowieka konieczne, gdyż bez niej nie potrafi on właściwie działać, gdyż nie zna planu Bożego względem siebie i świata. Człowiek, będący dla Hildegardy mikrokosmosem skupia i odbija w sobie całe piękno świata oraz cały jego układ, oczywiście w sensie symbolicznym. Wpatrując się w siebie, człowiek może najprędzej osiągnąć mądrość, która ułatwi mu racjonalne działanie. Hildegarda daleka jest bowiem od podejścia, iż jedynie ufna wiara i pokora wobec Boga są receptą na chrześcijańskie życie. Człowiek musi poznawać siebie i Stwórcę, musi rozważać swoje miejsce w świecie i powołanie, gdyż tylko w taki sposób będzie mógł włączyć się w harmonię stworzenia.

Stworzenie jest niejako lustrem, w którym człowiek może znaleźć ukryty obraz samego siebie. Zarówno słońce, planety, wiatry jak i elementy świata stworzonego zawierają odbicie boskiej Prawdy i zachęcają człowieka do wkroczenia na drogę powrotu do Boga. Powrót ten, po pierwotnej katastrofie, jaką był grzech pierworodny, jawi się jako naczelne i fundamentalne zadanie człowieka. Aby jednak powrócić, trzeba wpierw poznać drogę, którą należy iść i cel, 
który chcemy osiągnąć, potem możemy wybrać najodpowiedniejsze metody. Całe dzieło ksieni z Bingen jest próbą nakreślenia takiej duchowej mapy, którą każdy człowiek mógłby wykorzystać we własnym życiu. Mapy, która pozwoli odnaleźć się człowiekowi pośród innych dzieł natury, mapy, która powie mu, jakie ma powołanie. A ma ono wymiar kosmiczny. Tylko bowiem przez powrót człowieka do Boga może dokonać się powrót całego stworzonego świata, który został dany człowiekowi właśnie jako miejsce realizacji tego powrotu.

Cały więc stworzony świat jest specjalnie zaplanowanym miejscem, gdzie każda rzecz i każda aktywność zawiera odniesienie do rzeczywistości wyższej, duchowej i odsyła człowieka ostatecznie do Boga jako celu ostatecznego. Warto tu podkreślić, że droga powrotu biegnie poprzez świat materialny, z całą jego fizycznością, braną w najbardziej dosłownym sensie. Hildegarda nie jest myślicielką, która wzywałaby do pogardy światem czy ucieczki od niego. Jako dzieło Boże zasługuje on na podziw i szacunek, jest swego rodzaju księgą (księgą natury), którą trzeba się nauczyć czytać.

Podstawą jest tu myślenie symboliczne, które Hildegarda wykorzystuje w najróżniejszej postaci. Symbolem jest praktycznie wszystko, gdyż wszystko jest stworzone przez Boga. Symbole mogą odnosić się do sfery duchowej, moralnej czy intelektualnej. Znajomość ich może mieć bezpośredni wpływ na życie ludzkie - Hildegarda znana była jako zielarka i uzdrowicielka, która swą wiedzę o roślinach wykorzystywała do leczenia ludzi. Wielość symboli (Hildegarda stworzyła nawet nowy język), metafor, niespotykanych porównań utrudnia często dokładne zrozumienie treści jej nauczania.

\section{METAJĘZYK I FALSZYWY JEZZYK A POWINNOŚĆ}

Hildegarda porusza się w symbolicznym sposobie myślenia i wyobrażania jej czasów. Same wizje są bezpośrednim przeżyciem wewnętrznego zmysłu, interpretacja ich także porusza się po torach umysłowości jej czasu. Tak więc przykładowo, trzy planety ponad słońcem w jednej z wizji to symbol Trójcy. Stoją ponad słońcem, które 
symbolizuje narodzonego Syna, dlatego iż tylko w takim kontekście może się objawić boskość Chrystusa, który zstąpił z nieba na ziemię.

Treść symboliczna jest $\mathrm{w}$ tym przypadku mocniejsza niż empiryczna prawda, prawda wizji nie jest de humano sensu. W pismach Hildegardy, z jednej strony kosmos w swym pięknie i zależności od praw natury tylko rzadko jest przedmiotem rozważania, podczas gdy, z drugiej strony, nie wizyjne, przyrodnicze pisma, choć często opanowane przez symboliczne myślenie, nie spychają przyrodniczych prawd na bok. Występuje tu następująca zależność: jeśli chodzi o konkretne działanie w świecie, np. leczenie choroby, to realne, empiryczne własności ziół mają całkiem inną wartość, niż kiedy chodzi o ich wartość symboliczną. Wartość empiryczna odgrywa tu tylko taką rolę, która wymagana jest do zrozumienia symbolu, jak w przypadku słońca, gdzie jaśniejący blask daje mu możność zaistnieć jako symbolowi narodzonego w Bogu Syna.

Specyfika spojrzenia Hildegardy odsłonić się może, kiedy w jej wypowiedziach odróżni się poziom przedmiotowy i meta przedmiotowy. W pismach przyrodniczych bowiem, przedmiotowe wypowiedzi odnoszą się do realnych własności rzeczy naturalnych, których przyczynowy stosunek do człowieka oparty jest potem na zwykłej analogii. Tak przykładowo, uważa Hildegarda mięso świni za niezdrowe, ponieważ jego ciepło łączy się z ludzkim i przez to nadmiar temperatury powoduje u człowieka złe czyny i obyczaje. Podczas więc, gdy przyrodnicze pisma mają głównie przedmiotowy charakter, to pisma wizyjne Hildegardy poruszają się głównie na metajęzykowym poziomie, co następująco można wykazać.

Druga wizja z Liber divinorum operum używa, bogatego w tradycję, obrazu człowieka kosmicznego, który potem w czwartej części Causae et curae będzie użyty do szczegółowego przedstawienia schematu: mikrokosmos-makrokosmos: Deus enim hominem secundam firmamentum plasmavi ${ }^{1}$. Wizja człowieka kosmicznego mieści się zatem w schemacie opisu przedmiotowego i meta przedmiotowego.

${ }^{1} \mathrm{H}$ i $1 \mathrm{deg}$ a rd is B inge n s is, Liber divinorum operum, w: Patrologia Latina, (dalej cyt. jako: LDO), $761 \mathrm{~B} / \mathrm{C}$. 
Wizja ta nie dotyczy bowiem realnych, empirycznych własności kosmosu, lecz raczej rodzaju i sposobu, w jaki człowiek, zmieniający się sam wewnątrz kosmosu, odnosi się i jak powinien odnosić się do stworzeń.

W Scivias I, 3 nie używa Hildegarda wprawdzie obrazu człowieka kosmicznego jednak człowiek pojawia się tu wyraźnie jak w Liber divinorum operum. Kula z piasku jasno wskazuje na człowieka, który wśród stworzeń Bożych, jako jedyna istota, stoi wyprostowany, pogrążony w głębokim rozmyślaniu i jest otoczony przez siły stworzeń tak, że w żaden sposób nie może być od nich oddzielony. Jedyna empiryczna cecha, którą przedstawia to połączenie między człowiekiem i ziemią, jest to piaszczysta natura ziemi, której odpowiada gliniasta materia u człowieka ${ }^{2}$. Wizje kosmiczne nie mówią więc wiele o właściwościach kosmosu, bardzo zaś wiele o stosunku człowieka do kosmosu, a dokładniej, mówią jak człowiek ma zrozumieć samego siebie w ca $\square$ ości kosmosu i mówią to w sposób, który nie ujawnia się człowiekowi z naturalnych własności kosmosu.

Przy ogólnym opisie wizji można rozróżnić więc różne poziomy. Wpierw same wizje, które widzącej nie udzieliły żadnych rzeczowych informacji o kosmosie, takim jaki przedstawia się poznaniu opartemu na naturalnych spostrzeżeniach. Kosmiczne wizje razem z dawanymi przez niebiański głos objaśnieniami mówią coś o stosunku między człowiekiem i kosmosem, i dlatego poruszają się $\mathrm{w}$ porównaniu $\mathrm{z}$ codziennym doświadczeniem rzeczywistości na meta poziomie. Mówią ponadto, jak człowiek odnosi się do świata i jak powinien się do niego odnosić. Dalej, od wizji trzeba odróżnić ich spisanie, które dostępne jest tylko dla czytelnika, nie pozwala mu jednak uczestniczyć w wizjach. Wreszcie są relacje o obrazach i języku, przez które wizje są objaśniane. Taka relacja znajduje się więc na meta poziomie.

Można więc rozróżnić trzy poziomy: pierwszy, naturalny, codzienne doświadczenie świata, od którego to poziomu widząca

2 H i 1 d e ga r d, Scivias, ed. A. Führkötter, Brepols 1978, (dalej jako Sc.), I, 3, 16, 293-300. 
uwolniła się podczas wizji. Drugi poziom to poziom wizji, na którym widząca stwierdzała, jakie miejsce zajmuje człowiek naprawdę w kosmosie i jak odpowiednio do tego ma się zachowywać. Trzeci poziom to spisanie wizji, przez co Hildegarda chciała udostępnić jądro wypowiedzi drugiego poziomu. Poziomy te da się wyjaśnić przez schemat przedmiot - meta przedmiot. Ale najpierw trzeba rozstrzygnąć, czy uprawnione jest mówić tu o poziomie przedmiotowym i meta przedmiotowym?

W lingwistyce język nazywa się językiem przedmiotowym wtedy, gdy jest „on przedmiotem metajęzykowego opisu” (a), „kiedy odnosi się do przedmiotów, które same nie są językowe” (b), „kiedy odnosi się do pozajęzykowych przedmiotów i kiedy jest zarazem przedmiotem metajęzykowego opisu" (c), przy czym stosunki tych możliwości wzajemnie są dysjunktywne. „Metajęzykiem jest każdy język..., który odnosi się do języka" " ${ }^{3}$. Metajęzyk jest zatem w każdym wypadku językiem o języku. Idąc za tą definicją tylko wtedy można rozumieć wizje jako metajęzykowe, kiedy operują językiem przedmiotowym. Ten język przedmiotowy ze swej strony może, nie musi jednak, odnosić się do nie językowych przedmiotów, tak że główne pytanie jasno zwraca się do tego, czy wizje posiadają język przedmiotowy wobec rzeczy, a jeżeli tak, to jaki.

Naturalnie w wizjach nie ma mowy dokładnie o języku. One odnoszą się raczej do całego człowieka w jego postawie wobec kosmosu i Boga. Można wyobrazić sobie przedmiot wizji jako pole trójkąta z człowiekiem, Bogiem i kosmosem, przy czym problem, że człowiek jest zarazem częścią kosmosu, pozostaje w tym momencie poza rozważaniem. Sama Hildegarda opisuje ten stosunek przez dosadną formułę, iż człowiek jest opus... Dei cum omni creatura existens. Nie ma wątpliwości, że wizje miały na względzie całość tego kompleksu relacji, a nie jakiś specjalny czy codzienny język w normalnym sensie.

${ }^{3}$ H. J. W e r n e r, Homo cum creatura. Der kosmische Moralismus in den Visionen der Hildegard von Bingen, w: A. Z i m m e r m a n n. A. S p e e r (red.), Mensch und Natur im Mittelalter, „Miscellanea Medievalia“, t. 21/1, Berlin-New York 1991, s.73. 
W stosunku człowieka do kosmosu idzie zawsze o całego człowieka w jego bycie i zachowaniu ${ }^{4}$. Mimo tego użycie językowych kategorii do opisania tego stosunku nie jest obce istocie myśli Hildegardy. Jest niezwykłe jak często, w swej interpretacji niebiańskiego wyjaśnienia wizji, używa ona językowych pojęć. Wielka wizja końcowa z LDO może to zobrazować. Antychryst kreśli na czołach swych członków pismo, aby nad nimi zapanować. Pismo to będzie sprawiać, że ludzie zaprą się Boga jako Stwórcy i będą żyli w oczekiwaniu większych darów duchowych, niż te, które Chrystus obiecał swym wierzącym. To pismo będzie nakłaniać do odejścia od Boga, tak że ludzie będą czcili tylko to, co ujrzą jako Lucyfera. Bóg będzie jednak sprawcą zniszczenia tego pisma i powstanie pismo Ducha Świętego ${ }^{5}$.

Mowa jest więc o dwóch pismach, tj. o dwóch systemach znaków, które rzeczywistość w całości - Boga i stworzenie - pozwalają zobaczyć w różnych perspektywach. Pismo „wyciśnięte” w człowieku jest językiem, który odnosi się do stosunku między człowiekiem, stworzeniem i Stwórcą. Antychryst, który przynosi nowe pismo, dostarcza człowiekowi nie tylko nowego sztucznego systemu znaków, który nie dotyczy istnienia człowieka: on raczej zmienia przez to pismo stosunek człowieka do siebie samego i do świata. Sam świat jest przez to bardziej dotknięty niż przez jakąś zewnętrzną interwencję. Z wielu miejsc pism Hildegardy wynika wyraźnie ontologiczny charakter tego języka. Antychryst działa narzucając człowiekowi nowe pismo i przez to inny obraz świata, przy równoczesnej zmianie i zakryciu sensu stworzonego świata.

Świat stworzony zostaje zanurzony przez nowe znaki i pisma w ułudę, która omamia człowieka pięknością i błogością. To, że jest to rezultat nowych znaków językowych, które tworzą nowy związek między stworzonym światem i człowiekiem i przez to oba elementy relacji zmieniają się, podkreśla Hildegarda bardzo wyraźnie.

${ }^{4}$ C. M e w s, Religious Thinker: „A frail human being” on fiery life, w:. B. N e w m a n (ed.), Voice of the living Light. Hildegard of Bingen an her world, Berkeley-Los Angeles-London 1998, s. 58.

${ }^{5}$ LDO, PL 1032B. 
Wszystko to oczywiście, mierzone względem prawdziwego, ostatecznego bytu rzeczy, pozostaje tylko kłamstwem i ułudą bez żadnej podstawy. Zwrot do prawdziwego języka zostanie dokonany przez dwóch proroków Eliasza i Henocha, którzy wrócą na „końcu czasów" i dadzą inne znaki (signa), które zniszczą działanie fałszywych znaków.

Prawdziwy, ostateczny byt rzeczy nie jest więc naruszony przez fałszywe znaki, co jednak nie oznacza, że pismo tj. język (znaki), przez które człowiek poznaje świat, było wobec niego czysto zewnętrzne. Fałszywe znaki, przez które człowiek pozwolił się omamić, łączą się ze stworzonym światem, jak grzech ludzi łączy się z naruszeniem elementów świata. $Z$ tego nie wynika żadna ostateczna zmiana w sensie metafizycznym, ale jednak ciężkie naruszenie przebiegu funkcji elementów świata stworzonego. Ontologiczne znaczenie języka staje się w omówionym miejscu wyraźne jeszcze przez to, że prorocy Henoch i Eliasz wprowadzają zmianę tylko przez to, że zmuszają stworzony świat do zrezygnowania z samozasłonięcia i do prezentacji w nowych, tym razem prawdziwych tzn. ostatecznych znakach

To znaczenie języka wypływa też z różnych interpretacji relacji o stworzeniu i stanie pierwotnym człowieka. Szczególnie jasno wychodzi to w wizji czwartej w LDO, gdzie człowiekowi, po jego stworzeniu przez Boga, przekazane zostaje zadanie, aby przez intelektualnie odciśnięty ,język stworzenia” rozgłaszał stworzony cud: Deus enim omnes creaturas propter illum creavit, eique in oculo veri amoris per rationalitatem ipsum praedicare et laudare concessit ${ }^{6}$. We wciąż ponawianych zwrotach opisuje Hildegarda znaczenie słowa, które łączy razem człowieka, stworzenie i Boga, przy czym prolog Ewangelii św. Jana tworzy tu podstawę interpretacyjną. Jasne sformułowanie: parvum opus, quod homo est, in me dictavi ${ }^{7}$ jest naczelną zasadą dla Hildegardy. Bóg wypowiada w sobie „mały świat” tj. człowieka, który przez to staje się mikrokosmosem i wyrazem całego

\footnotetext{
${ }^{6} \mathrm{LDO}, \mathrm{PL} 885 \mathrm{~B}$.

7 LDO, PL 889B.
} 
stworzonego świata. Jeżeli więc dalej stwierdza: Deus in homine tam superiores quam inferiores creaturas signavit ${ }^{8}$, to używany także w wielu innych miejscach termin signatio jest więcej niż tylko sposobem mówienia. Oznacza on, że w językowych znakach spotykają się człowiek i stworzenie, gdyż człowiek pojmuje (ogarnia) istoty stworzeń nie inaczej jak przez nazwy (nomina), które są wyrazem stworzonego świata. Słowo, pochodzące z boskiego Początku, przedstawia rodzaj centrum intencjonalnego, w którym łączą się człowiek i stworzenie. Słowo budzi stworzenie do życia i zarazem jest życiem dla ludzi: vita quae creaturas suscitaverat, vita vitae hominis, quia per eam vivit ${ }^{9}$.

Język, który jest boskiego pochodzenia, wydobywa życie i istotę stworzonego świata. Quando enim verbum Dei sonuit idem verbum in omni creatura apparuit, et idem sonus in omni creatura vita fuit ${ }^{10}$. Język człowieka pomaga światu w samowyrażaniu się i prowadzi go z powrotem do jego boskiego początku, dlatego człowiek powinien poznać stworzenia tzn. przez nazwy opisać, i postawić je w swoim świetle ${ }^{11}$. Język jest zawsze jednością zewnętrznych znaków i rozumu.

Kiedy Hildegarda mówi, że człowiek rozpoznaje rzeczy przez to, że nadaje im nazwy, to odnosi się ona przez to, z jednej strony, do mikrokosmicznej formy bytu człowieka, w którego cielesności „wyrysowana” jest całość świata jak w czwartej wizji w LDO, z drugiej strony zaś, odnosi się do szczególnych funkcji poznawczych człowieka, które wypełniają się w jedności intelektu i słowa, a więc w języku. Już jej własna próba stworzenia tajemnego języka ${ }^{12}$

8 LDO, PL 886C.

9 LDO, PL 891C/D.

${ }^{10}$ LDO, PL 890D.

11 „Homo enim quasi lux aliarum creatuarum in terra commemorantium est, quae multoties ad ipsum currunt, et qui eum multo amore lambunt”. LDO, PL 895A.

12 Jedna praca wymyka się z ram pism Hildegardy, pismo o nieznanym języku. Wspólnota uznała je za tak ważne, że zaraz zostało włączone do zestawionego po śmierci Hildegardy Riesenkodex i zostało też wspomniane w aktach beatyfikacyjnych. O wadze tego języka pisze Hildegarda w liście z 1154 do papieża Atanazego. Manuskrypt nieznanego języka zawiera zapis obcego alfabetu pod odpowiadającymi 
wskazuje na znaczenie, które widziała w zdolności mowy człowieka. Jeżeli wszystko, co jest w Bożym porządku daje sobie nawzajem „odpowiedź” to człowiekowi z jego specyficzną zdolnością mowy przypadło bez wątpienia szczególne zadanie

Wywody te wychodzą od tezy, że kosmiczne wizje mają się do empirycznych wypowiedzi tak, jak metajęzykowy poziom do przedmiotowego. Metajęzykowy charakter posiadają wizje wtedy, gdy mają za przedmiot stosunek człowieka do stworzonego świata, ale nie interpretują go w językowych kategoriach. Stosunek człowieka do stworzonego świata jest na tyle określony językowo, na ile określone rozumowo językowe znaki w ich ogólności wyznaczają horyzont, w którym stworzony świat jest tłumaczony. W ,świetle” języka zjawia się świat, albo w prawdziwym kształcie, albo jak przy pojawieniu się Antychrysta, w fałszywym. Zatem wizje, mówiąc o stosunku między człowiekiem, stworzonym światem i Bogiem, mówią zarazem o języku, dzięki któremu człowiek panuje nad światem.

\section{ZDANIA ONTOLOGICZNE I NORMATYWNE}

$\mathrm{Na}$ jakim poziomie poruszają się pisma wizyjne Hildegardy? Jak dalece mają metajęzykowy charakter? Przy odpowiedzi na to pytanie trzeba zwrócić uwagę na wyraźną moralną intencję, która kieruje kosmicznymi wizjami. Językowi przedmiotowemu odpowiadają w wizjach związki człowieka ze stworzonym światem, które są określone przez nazwy, a więc przez język. Inaczej jednak niż na danym w pierwszym przykładzie poziomie, opisują wizje nie tylko rzeczywiste zachowanie wewnątrz wcześniej danych granic, lecz idą

\footnotetext{
łacińskimi literami, gdyż do tego języka przynależy własny obraz pisma i ponad 1000 słów. Słowa nie są ułożone alfabetycznie, lecz rzeczowo. Listę zaczynają słowa: Bóg, anioł, diabeł, człowiek, ale nie ma zdań i słów zawierających czynności.. Nie chodzi tu tylko o obce słowa, ale o ignota lingua. Co i ile Hildegarda mówiła siostrom w obcym języku i o nim, nie wiemy. Na pewno nie była to zabawa, ani szyfrowanie wiadomości. Jest chyba tylko jedno wyjaśnienie: Hildegarda mówi tu językiem otrzymanym w słyszanych wizjach. E. G r o n a u, Hildegard von Bingen, Stein am Rhein 1991, s. 231-233.
} 
dalej w sensie normatywnym. Wizje mają wprawdzie na względzie w swych wypowiedziach także rzeczywiste zachowanie człowieka, jednak nigdy nie można wątpić w to, że chodzi o wezwanie skierowane do człowieka. Tworzą razem syntezę zdań normatywnych i bytowych. $Z$ pewnością nie jest to przypadek, że wizje pełne są jednoznacznych wezwań, które pojawiają się w standardowych sformułowaniach: Scribe quae vis et audis, Clama ergo et scribe sic. Te wezwania mają nie tylko napomnieć człowieka, ale skłonić go do zmiany życia.

Kiedy mowa jest o fałszywej, zwodzącej człowieka mowie Antychrysta, to wydaje się ona odpowiadać drugiemu przykładowi, gdyż mówi się o fałszu i prawdzie. Mimo tego wychodzą na jaw w wizjach pewne intencje. Wizje chcą człowiekowi nie tylko powiedzieć, że on wewnątrz języka, którego używa, mówi coś fałszywego. Raczej chcą człowiekowi powiedzieć, że jego język w ogóle jest przeniknięty przez fałsz. To odnosi się głównie do języka stworzonego przez Antychrysta, ale także do języka ludzkiego po grzechu: jest on przeniknięty diabelskimi tzn. zwodniczymi znakami, które człowiekowi zasłaniają stworzony świat w jego prawdzie. Hildegarda permanentnie wskazuje też na rzeczy, które mogą się zdarzyć i rzeczywiście zdarzają się, ale wymagają nowego i lepszego języka do ich opisu. Ujawnia się to w bardzo fundamentalny sposób w myśli, że stworzenia przez per tubam vocis w człowieku, powinny głosić chwałę Boga, człowiek natomiast, pozwalając prowadzić się przez fałszywe znaki, tylko niedoskonale realizuje to zadanie, tak że elementy świata skarżą się na człowieka i oburzają się na niego: Creatura... homine inobbedientiam arripiente, ita quod Deo inobediens fuit et tranquilitatem suam relinquit et inquitudinem suscepit ${ }^{13}$.

Wizje Hildegardy odciskają więc charakterystyczny dla wczesnego średniowiecza splot zdań bytowych i normatywnych, splot ten polega głównie na tym, że kosmos jest określony w swym obecnym kształcie przez wzajemność bytu i powinności.

${ }_{13}$ Sc., III, 5, 17, 471-475 
Trzeba tu wrócić do wizji sfer kosmicznych. Ciemny północny obszar jest miejscem przebywania diabła, nad którym po jego upadku nie świeci słońce. Jest opanowany przez ciemność, przez którą także człowiek jest pochwycony. Dobro i zło przeplatają się w tu jak różne fazy księżyca, i zmieniają się jak ciemne i jasne pory roku, i tak samo zmienia się moralne nastawienie człowieka. Tak bowiem jak błoto ziemi, spowodowane przez zmianę z zimnej na ciepłą porę przygotowuje ją do owocowania, tak dusza, gdy uległa cielesnym pokusom i leży w grzechach, przypomina sobie dobro i zwraca się ku cnotom.

To brzmi prawie tak, jakby człowiek był, odpowiednio do swego naturalnego stanu powiązania w kosmosie, zmuszany periodycznie do zła i faktycznie nie mógł z własnej siły uwolnić się od swej kondycji spowodowanej przez grzech. Nie jest to prawda. To, że może on w swym konkretnym, indywidualnym czynie, we współdziałaniu własnej siły z Bożym działaniem, zdecydować się na dobro i przez to być odpowiedzialnym za swe czyny, jest podstawą do imperatywnego charakteru pism wizyjnych i przez to także do skrzyżowania bytu i powinności, którego kosmiczny fundament jest wciąż uwyraźniany w pismach Hildegardy.

Zrozumienie tego związku może przybliżyć szczególna rola, którą odgrywa w wizjach Hildegardy wiatr. $Z$ jednej strony, oznacza on dynamiczną siłę kosmosu, a z drugiej, także główną siłę duszy, która decyduje o moralnym stanie człowieka. Wiatr jest więc także metaforą kosmicznej łączności człowieka. Dusza opisywana jest jako vivens scintilla et rationabile spiraculum ${ }^{14}$. Odpowiednio do czterech głównych wiatrów są więc cztery główne siły (vires) duszy: cogitatio, locutio, intentio, gemitus ${ }^{15}$. Łączą się one, odpowiednio ze zmieniającymi się kierunkami wiatru, skłaniając człowieka do wyboru zła lub dobra, co zakłada z kolei wiedzę o złu i dobru, a przez to główną cnotę discretio. Ona łączy człowieka z kosmosem, gdyż siła, by

\footnotetext{
14 LDO, PL 816A.

15 LDO, PL 841C.
} 
odróżnić dobro i zło została dana człowiekowi ut cum scientia illa omnes creaturas discernat ${ }^{16}$.

Już przy czterech głównych siłach duszy pojawia się locutio, które w żaden sposób nie stoi wyizolowane obok innych sił, lecz łączy się z nimi w dialogiczną jedność. To samo zresztą dotyczy innych głównych sił duszy jak: expiratio, scientia, sensus ${ }^{17}$ lub sensus, scientia, voluntas $i$ intellectus ${ }^{18}$. W jakim stosunku te różne siły stoją, pozostaje do końca niejasne w myśli Hildegardy. Istotne jest, że siły te nie są izolowane, lecz razem działają i wzajemnie się dopełniają, tak że dusza w swych siłach jest dynamicznym stanem równowagi. W wielu miejscach używa Hildegarda językowych pojęć, aby opisać czyny wypływające z głównych sił człowieka. Skoro tylko dusza porozumiewa się z czynami człowieka za pośrednictwem cnoty roztropności, pisze ona (scribit) w sobie przez tchnienie ducha (cum spiramine suo), i to pismo (hanc scripturam) wiąże w myśleniu (per cogitationes colligit), aby rozpoznać kwalifikację czynu, który także, jak formy innych rzeczy, w myśli ogląda. Myśli są jak tablica (sicut pugillaris) duszy ${ }^{19}$.

Tu pojawia się ponownie język jako człon łączący człowieka z samym sobą i ze światem, jako medium. Znaczenie języka wypływa $\mathrm{z}$ tego, że cała kosmiczna wizja, która przedstawia człowieka jako mikrokosmos, łączy się z interpretacją prologu św. Jana, a więc ze Słowem, które na początki było u Boga, stało się ciałem i zamieszkało między ludźmi. Słowo to jest życiem każdej istoty, pozwala się stopniować i określa też specyfikę mowy człowieka, gdyż: de eodem verbo rationalitas hominis opera sua operatur, et de eodem sono opera sua sonando, clamando et operando profert ${ }^{20}$. Naturalnie używane przez Hildegardę językowe kategorie nie odnoszą się w pierwszym rzędzie do ludzkiego języka w węższym sensie. Scriptura w duszy to

\footnotetext{
16 LDO, PL 920D.

17 LDO, PL 816B.

18 LDO, PL 874A.

19 LDO, PL 850A.

20 LDO, PL 890D - 891A.
} 
nie żaden zewnętrzny, lecz wewnętrzny język odniesiony do Słowa, przez które stworzenia powstały.

Pomimo tego nie można powiedzieć, że mowa jest tu o języku w jakimś niewłaściwym, metaforycznym sensie. Nazywając rzeczy swymi słowami, podnosi człowiek słowo w rzeczach do swego „światła”. On sam więc jest „światłem” reszty stworzeń, które cisną się do niego z miłością. Swym językiem bierze człowiek na swój sposób udział w uniwersalnym języku stworzenia, które z góry jest na niego skierowane. Człowiek, który nazywa rzeczy, uważa znaków stworzenia, a więc jego języka i wyraża je na swój własny sposób. Właśnie przez to realizuje człowiek boskie Słowo, które określa jego byt, tak samo jak byt innych stworzeń. „Słowo” jest tu terminem, który byt ludzki, stworzeń i boski łączy we wzajemnym związku. Nazywając rzeczy w odpowiedni sposób przemienia człowiek znaki stworzenia w swój własny język i przez to realizuje funkcję znakowania rzeczy, co pomaga stworzeniom nie tylko w ich samowyrażeniu się, lecz zarazem wskazuje na człowieka i na boski początek, łącząc je w jedną całość..

To wszystko odtwarza stan powinności, któremu człowiek w swym historycznym bycie tylko niedoskonale odpowiada. Kiedy kosmiczne wizje mówią o prawdziwym stosunku człowieka do stworzeń, o jego prawdziwym miejscu w kosmosie tj. o jego prawdziwej odpowiedniości wobec ziemskich rzeczy, jest w tym zawsze zawarty wyraźny imperatywny moment: wizje, których widząca nie może zachować dla siebie, mówią człowiekowi, jakim językiem musi mówić, aby swoje prawdziwe miejsce w kosmosie nie tylko metaforycznie, ale i faktycznie zająć.

Jak wygląda ten prawdziwy język, tzn. jakie są strukturalne własności stworzenia, które człowiek przez swe słowo powinien oświetlić? W kosmicznych wizjach wciąż są nazywane własności, które akcentują to, co łączy stworzenia i wzajemnie je przyporządkowuje, własności, które łączą się z dialogiką stworzonego bytu.

Wiatr odgrywa tu jako element szczególną rolę, jak okazało się już wcześniej. Kosmiczne własności jak światło i dźwięk są wciąż ponownie omawiane, głównie dlatego, że nie mogą być rozpatrywane 
w izolacji. O dźwięku mówi Hildegarda: Unumquodque elementum, secundum quod constitutum est a Deo, sonum habet, quo omnes sicut sonus chordarum et cithrae in unum coniuncti sonat ${ }^{21}$. Współdziałanie, które tu wyraża się jako consonare określa stosunek sił i wyznaczników bytu. Odnosi się to też w detalach do człowieka. Częste też analogie do Trójcy Świętej ukazują najgłębsze współdziałanie wszystkich elementów świata: tres vires in lapide, et tres in flamma, et tres vires in verbo sunt. Słowo samo rozkłada się na sonus, virtus et flatus.

\section{DIALOGICZNE NAPIECIE}

Zasady tego współdziałania odnoszą się do całego kosmosu, są jednak, jak wyraźnie pokazuje Scivias I, 3, nie wolne od napięć: ciemny ogień znajdujący się pod jasnym, symbolizuje ukaranie złych ludzi. Odpowiadająca temu wizja w LDO wskazuje wyraźnie na to, że oba kręgi ognia łączą się. Napięcie wyraża się też przez to, że wiatry, istota kosmicznej siły, stabilizują się wzajemnie, podobnie jak człowiek, który trzyma ramię swego wroga, ażeby ten go nie zabił: Sic creatura per creaturam continetur et unaquaeque ab alia suste$n_{\text {atur }}^{22}$. Kosmos jest harmonijną, ale też pełną napięć równowagą. Dynamika wzajemnego zazębiania jest podkreślona przez godne uwagi zdanie, że Bóg tak stworzył stworzenia, że jedno pochodzi $\mathrm{z}$ innego: Deus creaturas creavit, deinde alias es aliis produxit ${ }^{23}$. To, że Hildegarda widzi uniwersalną zależność rzeczy w sensie dialogicznym, widać w tym, że do opisania tego ontologicznego prawa używa dużo językowych kategorii. Przy opisie wzajemnego udzielania się sobie stworzeń używa bardzo konkretnych obrazów, że zioła przez swe kwiecie udzielają innym ziołom zapachu, że kamień daje innym kamieniom blask.

\footnotetext{
${ }^{21}$ LDO, PL 1049B.

22 LDO, PL 776B.

23 LDO, PL 937D.
} 
Jeżeli podstawowe prawo bytów zgodne jest z wymogami powinności, to istnieje zależność, a wtedy nieprawda, zło, to, co nie „powinne” istnieje w izolacji, w sobie zamknięte. To są określenia, którymi Hildegarda opisuje zło i jego personifikację szatana. Po swoim upadku diabeł został surowiej ukarany niż wszyscy, którzy za nim poszli, bo spoglądał tylko na siebie, podczas gdy zwolennicy jego zwrócili się nie na siebie, ale właśnie na niego. Kosmiczne zło, spowodowane przez upadek diabła istnieje więc w łączności samoodniesienia, które jest jeszcze gorsze niż skierowanie do innego, danego uprzednio zła. Nie ma wątpliwości, że ten kosmiczny stan rzeczy odbija także pojmowanie moralności przez Hildegardę. Etyka człowieka nakierowana jest na kosmiczną łączność i sprawia, że człowiek łączy się z podobnymi bytami, ale prowadzi też dialog z kosmosem. Jeżeli nie idzie za tą zasadą, to zależy tylko od swojej woli i przez to od zła. Jak to prawo odbija się w moralności i w emocjach pokazuje zdanie: Plenum... gaudium utilitatis ex se ipso homo habere non potest, nisi aliud ab alio percipiat; et cum per alium utilitatis gaudium intellexerit exsultationem magnam in corde suo exinde habebit ${ }^{24}$.

Tu odbija się wyraźnie dialogiczne prawo kosmosu w ludzkiej duszy: otwarcie na zewnątrz, responsum dare jest dla niej nie tylko moralnym obowiązkiem, lecz odpowiada istocie człowieka, który równocześnie może cieszyć się z samorealizacji. Współczesne przeciwstawienie między altruizmem a egoizmem nie odgrywa dla Hildegardy żadnej roli. Mówi ona krótko: Qui alii ministrat, se ipsum respicit.

To, że tę bazę moralnego postępowania, która określa człowieka jako opus alterum per alterum, rozwija Hildegarda skierowując się na dialogiczną strukturę kosmosu, jest niewątpliwe. Człowiek „odpowiada" kosmosowi i Stwórcy w swym postępowaniu i bycie. On „odpowiada" w dokładnym sensie przez to, że nadaje poszczególnym bytom i formom życia nazwy, i w dalszym sensie przez to, że jego własna natura, aż do wnętrza jego życia pokazuje strukturalne

24 LDO, PL 959D. 
paralele z kosmosem. To jest sens mikrokosmicznej miary człowieka, która jest opisana w czwartej wizji Liber divinorum operum.

Łączność człowieka z kosmosem jest więc zawsze interpretowana dialogicznie, co zawiera pewne napięcie. W pierwotnym stanie człowiek był osadzony w terra viventium, obcowanie $\mathrm{z}$ innymi stworzeniami było łatwe, podczas gdy one okazywały człowiekowi szacunek, nie tracąc jednak swej tożsamości ${ }^{25}$. Po grzechu została zniszczona harmonia, a w stosunki między stworzeniami wszedł moment zagrożenia, człowiek jednak nie stracił kosmicznej łączności z bytami: Deinde homo cum creatura operari coepit, quia sicut ignis alia quaeque ascendit et perficit, ita et homo cum reliqua creatura est ${ }^{26}$. Łączność z ziemią pozostała w człowieku, tak że on istnieje nadal secundum naturam terrae, razem jednak z ambiwalencją, którą sam przez grzech wprowadził. Do tego związku należą uwagi, które Hildegarda poświęca zmysłowemu wyposażeniu człowieka, takie jak uwydatnienie przez nią tych elementów i własności, które przenikają cały kosmos (powietrze, światło, dźwięk), a którymi natura włada tak samo jak włada nimi dusza i ciało.

Trzeba wspomnieć też o napięciu, które określa stosunek człowieka do kosmosu i przez to do natury na bazie ich podstawowej łączności. Można je sprowadzić do kombinacji antropocentryzmu i dialogiki. Kosmicznie odniesiony antropocentryzm przenika dzieło Hildegardy i wyraża się w obrazie człowieka-kosmosu. Bóg przekazał człowiekowi całe stworzenie, ażeby mógł on „w” nim i „,z" nim działać: omnes creaturas ut cum ipsis operaretur ei dedit ${ }^{27}$.

Antropocentryzm Hildegardy i całego średniowiecza jest jednak inny od współczesnego antropocentryzmu Kartezjusza, który oddzielił by towo człowieka i naturę i przez to dał człowiekowi możliwość, aby zinterpretować naturę jako wolną od jakości, rozciągłą rzecz. Dla Hildegardy istnieje bytowa łączność, z której wynika, że wszystko, co robi człowiek, ma także jakościowe oddziaływanie na naturę. (Tak

\footnotetext{
25 LDO, PL 964D-965A.

26 LDO, PL 91 D.

27 LDO, PL 774A.
} 
po grzechu elementy popadły w nieład i podniosły z powodu zniszczenia kosmicznej równowagi srogą skargę przeciw człowiekowi).

Taka współzależność ma za założenie odrębne stanowisko człowieka, którego czyny mają następstwa dla stworzenia jako całości. Natura i człowiek ,odpowiadają" sobie wzajemnie, przy czym człowiekowi przypada dominująca rola. Jak dosłownie ujmuje Hildegarda ten dialog, pokazuje jej uwaga, że w godzinie śmierci człowiek może, kiedy nie ma księdza lub innego człowieka, wyspowiadać się elementom (coram elementis) ${ }^{28}$.

Pierwsze napięcie w stosunku człowiek-natura tkwi więc w rozbieżności między prawdziwym określeniem miejsca człowieka pośród kosmosu a jego faktycznym postępowaniem, przez które kosmiczna równowaga jest niszczona.

Z tym związane jest drugie napięcie, które ma związek z odrębnym miejscem człowieka w kosmosie i możliwe, że Hildegarda nie była tego świadoma. W kosmicznych wizjach znajdują się, z jednej strony, wypowiedzi, które stosownie do miejsca człowieka w kosmosie mówią o przychylności, nawet o najmocniejszej miłości (fortissima dilectione) do stworzeń i stworzeń do człowieka: (creaturae) multoties ad ipsum currunt, et qui eum multo amore lambunt. Unde etiam et homo a creatura in cuius amore ordet, ea vult, diligenter saepius inquirit ${ }^{29}$. Z drugiej strony, Hildegarda nie pozwala wątpić, że człowiek powinien używać innych stworzeń do swych potrzeb, także wtedy gdy spotka je przez to cierpienie. Tak poleca, przy żółtaczce nadziać nietoperza i żyjącego przywiązać do pleców chorego. Sprzeczność rozbrzmiewa też, gdy Hildegarda w jednym i tym samym zdaniu mówi, że stworzenie kocha człowieka, człowiek jednak ujarzmia je tak, jak to jest mu potrzebne: homo omni creaturae

28 „Quod si in hora mortis suae positus remedium vulnerum peccatorum suorum quaerit, sed tamen sacerdotem cui peccata sua confiteatur habere non poterit, tunc alii homini quem eodem tempore opportunum habet ea manifestet, vel si tam repente nullum hominem habere potest, ea mihi coram elementis cum quibus etiam illa perpetravit ex intimo affectu cordis sui aperiat. Et ego devotionem cordis eius videns paenitentiam eius non abicio". Sc., II, 85, 2420-2427.

29 LDO, PL 895A. 
dominantur, eam ad omnem necessitatem suam sicut desiderat sibi subiiciens ${ }^{30}$.

$\mathrm{Z}$ dialogiki, tym razem mniej w połączeniu $\mathrm{z}$ antropocentryzmem lecz raczej z myślą o transcendencji, pojawia się jeszcze trzecie napięcie. Dialogiczny stosunek porządkuje wzajemnie partnerów, ale zarazem oddziela ich wzajemnie, tak że wzajemnie stają w stosunku inności. Inność, która nie jest do oddzielenia od dialogiki, ukazuje się u człowieka, który łączy w sobie wszystkie siły kosmosu, w szczególny sposób, mianowicie tak, że on przy wszystkich podobieństwach jest także całkiem inny od reszty stworzenia ujętego w całości. Ujęcie, które tę inność akcentuje i skierowuje moralność człowieka do nie-ludzkiej natury, porusza się pod wpływem języka Antychrysta, którego pismo mówi np. człowiekowi, że nakaz wstrzemięźliwości jest przeciw naturze.

Według Hildegardy człowiek oscyluje między pogardą świata i jego afirmacją. Discretio łączy człowieka ze światem i dzieli go zarazem, i obie te rzeczy człowiek musi widzieć jednocześnie. Jest do tego zdolny tylko dlatego, że samo stworzenie, które w człowieku jakby dochodzi do świadomości, wskazuje ponad siebie, na boski początek. Napięcie, które towarzyszy człowiekowi podczas jego ziemskiego bytu nie znika oczywiście przez tę świadomość. Hildegarda szkicuje je nieraz przez prawie dialektyczne zwroty np. kiedy oddaje słowa boskiego głosu: Bonum ergo quod habes a me, diligere debes adversum te.

Jednak człowiek może żyć wobec porządku stworzenia, w miłości, pokorze i pokoju, i przez to przestrzegać zasad, z których wszystko powstało, co Bóg stworzył. Wizje, ukazujące właściwy porządek stworzenia i miejsce w nim człowieka powinny mu już teraz w tym pomóc, miedzy innymi poprzez uświadomienie znaczenia języka, którym się posługuje. Język jednak, z którego zniknął fałsz i kłamstwa, w którym odbija się harmonia człowieka z sobą, kosmosem i Bogiem, odkryje się człowiekowi dopiero na końcu czasów. Dla

30 LDO, PL 951D. 
ludzi, do których zwraca się Hildegarda i dla niej samej jest on więc metafizyczną prawdą, ale jeszcze nie historyczną rzeczywistością.

\section{ZAKOŃCZENIE}

Św. Hildegardzie nie obcy był dorobek myślicieli chrześcijańskich, ale $\mathrm{z}$ racji pojmowania swych wizji jako boskich objawień nie dbała ona o zaznaczanie, iż korzysta z czyjegoś dorobku. Dorobek poprzedników traktowała jako wspólne chrześcijańskie dziedzictwo, z którego można swobodnie korzystać dla pouczenia ludzi. Swobodnie więc korzystała $z$ dostępnych jej idei czy dzieł teologicznych, aby wyrazić swą naczelną ideę o dynamicznej jedności stworzonego świata. Wizje, które były jej udziałem pokazywały świat tak, jak widziany jest z perspektywy Bożej, w całej swej harmonii, dynamice, ładzie i pięknie.

Tak chciała też widzieć świat Hildegarda, i tę wiedzę, to spojrzenie chciała przekazać innym osobom, aby każdy mógł mieć wgląd $\mathrm{w}$ istotę stworzenia. Wgląd, oparty jednak nie na samej wiedzy, ale na mądrości praktycznej, prowadzącej do celu wszystkich sworzeń - jedności i harmonii z Bogiem. Pierwotna jedność rozerwana została przez grzech pierworodny, który jednak nie zniszczył dzieła Bożego, ale sprawił, iż potrzebuje ono naprawy, uzdrowienia. Taką fundamentalną naprawą było odkupienie świata przez Syna Bożego było to zarazem otwarcie drogi do ponownej harmonii z Bogiem. W drodze do niej pomaga człowiekowi łaska Boża, Pismo Święte, sakramenty udzielane we wspólnocie Kościoła. W tej drodze powrotu chciała też pomóc Hildegarda z Bingen rysując przed chrześcijanami śmiałą wizję dynamicznej jedności całego stworzenia, wizję bardzo optymistyczną, ufną w dobroć Bożą, otwartą na porządek natury. Chciała, aby zainspirowani jej myślą ludzie gorliwie zaczęli realizować swoje powołanie. Miejsce człowieka w kosmosie jest bowiem wedle Hildegardy wyjątkowe. Tylko on ma wolność wyboru, tylko on może działać i zmieniać świat. Wizje Hildegardy miały właśnie pomóc ludziom zrozumieć, iż tylko działanie, które szanuje porządek 
stworzenia jest działaniem kontynuującym w pewnym sensie działanie Stwórcy, i tylko takie warto zatem podejmować.

\section{Around the Language of the Visionary Writings of St. Hildegard of Bingen Summary}

This article presents the concept of interpretation for an unusual symbolic language of Saint Hildegard von Bingen, who in her writing tried to express the unity of the entire creation and its dependence on the Creator. According to Hildegard, the whole world was planned and ordered by the Creator, and each thing is a kind of message, the word of the Creator, which is related to Him. The disaster, which was the original sin, disrupted the original harmony of the creation and introduced evil and falsehood to this creation. Relationships between earthly things, as well as between God and man were falsified. Thanks to her visions and their interpretations, Hildegard wants to show the real place of man in space. She wants to restore his ability to understand the world and read it as a message and the path to the Creator. Moreover, she intends to clean up the human language from the false. However, Saint Hildegard von Bingen knows quite well that the language without falsehood and lies, which reflects the harmony of man with cosmos and God, will be revealed to man at the end of time. For people, who have contact with Hildegard and for Hildegard, this language is the metaphysical truth, but not a historical reality (yet).

Słowa kluczowe: św. Hildegarda z Bingen, średniowieczna teologia, filozofia języka, wizja świata, średniowieczna koncepcja kosmosu

Keywords: St. Hildegard of Bingen, medieval theology, philosophy of language, vision of the world, medieval conception of the cosmos

Nota 0 autorze: doktor filozofii, doktorant na Wydziale Teologicznym UKSW; zainteresowania badawcze: filozofia i teologia średniowieczna, mistyka chrześcijańska, teologia kultury, teologia wizualna, teologia kina

\section{Bibliografia}

Gronau E., Hildegard von Bingen, Stein am Rhein 1991.

Hildegardis Bingensis, Liber divinorum operum, w: Patrologia Latina, 197, 730-1038. 
Hildegard, Scivias, ed. A. Führkötter, Brepols 1978.

Mews C., Religious Thinker: „A frail human being” on fiery life, w: B. N e w m a $\mathrm{n}$ (ed.), Voice of the living Light. Hildegard of Bingen an her world, Berkeley-Los Angeles-London 1998.

Werner H. J., Homo cum creatura. Der kosmische Moralismus in den Visionen der Hildegard von Bingen, w: A. Zimmermann. A. Speer (red.), Mensch und Natur im Mittelalter, „Miscellanea Medievalia“, t. 21/1, Berlin-New York 1991, s.73. 